\title{
Individuality of Transnational Entrepreneurs: A Missing Link
}

\author{
H.V. Mukesh and Dr. Babu Thomas
}

\begin{abstract}
Transnational entrepreneurs are major agents of trade and commerce in globalized world. These distinguished categories of entrepreneurs engage in trade and commerce at two different environment i.e. home countries and host. This zeal and force of transnational entrepreneurs moves the world of trade and commerce as they confront the unknown and step forward to create the future.
\end{abstract}

As the part of globalization, transnational entrepreneurs have attracted researchers from different disciplines. The knowledge on transnational entrepreneurs is still in its budding stage, it mainly focuses on sociological aspects, but individual aspects like personality traits and behavioral aspects of transnational entrepreneurs are still untouched. The limitations of existing literatures on transnational entrepreneurs are as follows.

a) It has not concentrated on individuality (personality traits and behavioral aspects) of transnational entrepreneurs.

b) It has not highlighted on the antecedent factors affecting the growth of transnational entrepreneurs (like transnational entrepreneurs' entrepreneurial potential, motivation, leadership skills etc).

c) The literature is limited to the scope, nature and resources required.

The review of literature has highlighted the importance of individual factors over other factors in the process of new venture creation. Entrepreneurial research from the past has been developed with this big debate of personality, behavior and motivation factors. It is also stated that motivation and individual interest are the major abilities of transnational entrepreneurs to gain competitive advantage against other players in multiple environment. Developing these missing links and filling the existing gaps is important for better understanding of transnational entrepreneurs.

Psychological based research has reinforced curiosity in entrepreneurs' personal characteristics as predictors of achievement by moving ahead of the past focus on traits to learn competencies, motivation, cognition and behavior. Further recent literature has emphasized on some of the key individual character like entrepreneurial potential, achievement motivation and leadership skills, which are crucial for new venture creation and success of transnational

H.V. Mukesh, Research Scholar, St. Aloysius Advanced Research center, Aloysius Institute of Management and Information Technology, Mangalore, Karnataka.E-mail:hv.mukesh@gmail.com

Dr. Babu Thomas, Dean, Research, Aloysius Institute of Management and Information Technology, Mangalore, Karnataka. E-mail:babuthomas@staloysius.ac.in

DOI: 10.9756/BIJIEMS.8140 entrepreneurs in complex environment. In this paper an attempt is made to relate the individual aspects of entrepreneurs with transnational entrepreneurs and coimmigrants. We have also developed a model for understanding how these key individual factors like entrepreneurial potential, achievement motivation and leadership skills affects the transnational entrepreneurial activity. The model states that the individuality of transnational entrepreneurs will initiate entrepreneurial activity i.e. people with high entrepreneurial potential, achievement motivation and leadership skills will tend to take up entrepreneurial activity against the fellow co-immigrants. The model needs to be tested for great insight on individuality of transnational entrepreneurs. This paper can also be the foundation for developing other individuality factors which are superior in transnational entrepreneurs.

Keywords--- Transnational Entrepreneurs, Entrepreneurial Potential, Achievement Motivation and Leadership Skills

\section{INTRODUCTION}

$\mathrm{T}$ HE world of business is now moving rapidly towards free market economy as a model for economic growth and development (Kuratko, 2007). The human effort towards building globalized world is at progress. Economic ties, trade and commerce between countries are the bridge towards globalized world. This needs multi-dimensional effort at micro and macro levels. Global leaders are playing their role at macro level, but we need some strong foot soldiers at micro level to push the process of building globalized world. The search of identifying such key players leads us towards transnational entrepreneurs. Entrepreneurs are the major factors of the knowledge economy, investment in information and human capital generate greater economic growth and development (Landstrom, 2008). This zeal and force of transnational entrepreneurs moves the world of trade and commerce as they confront the unknown and step forward to create the future (Kuratko, 2002). As the boundary between countries reduced due to advancement of information and communication technology, migration is commonly observed. Growing transnational links from migrants is critical in shaping economic relations among countries (Light and Gold, 2000). Transnational entrepreneurship is a rapidly emerging topic of international business. Approximately $3 \%$ out of total world's population are immigrants accounting for $10 \%$ population leaving in developed countries (Riddle, 2008). Chinese and Indians are leading in developing transnational business ties (Bagwell, 2007). 
The paradigm of transnational entrepreneurs as part of globalization has attracted researchers from many disciplines such as sociology, anthropology, economics and international business management (Light, 2007; Portes, 1987; Portes et.al, 2002; Saxenian, 2006). The role of transnational entrepreneurs involves entrepreneurial action that are carried out in a crossnational situation, and started by actors who are rooted in at least two different social, cultural and economic environments (Drori et al, 2009). The growing importance for developing transnational entrepreneurs is increasing. Authorities and policy makers are in search for such answers. The research need to be focused on identifying and developing transnational entrepreneurs. Supply of entrepreneurs is of great importance and identifying the supply side factors is critical in policy matters (Hamilton and Harper, 1994) but the economic theories have failed to explain the supply factors of entrepreneurs (Baumol, 1968). Further the trait and behavioral approaches have emphasized on individual aspects and behavior as the major factors for supply of entrepreneurs (Hamilton \& Harper, 1994). Psychological based research has reinforced curiosity in entrepreneurs' personal characteristics as predictors of achievement by moving ahead of the past focus on traits to learn competencies, motivation, cognition and behavior. (Baum \& Locke, 2004). This evolution in the field of entrepreneurship research initiates further investigation of key personality and behavioral factors from different dimensions. There are many such lead factors triggering the entrepreneurial activity. The study has considered three such factors for understanding individuality of transnational entrepreneurs. Entrepreneurial potential is one such element which perceives opportunity present in environment, also possesses the personal characteristic and self-confidence to launch a new venture (Mueller \& Goic, 2002). Achievement motivation is another important factor which is related to individual motivation for starting new venture (Loon \& Casimar, 2008). Leadership skills are the center of entrepreneurial activity, the ability of an entrepreneur to lead his team will decide the success or failure of entrepreneurship (Chen, 2007). Studying these three predecessor factors of transnational entrepreneurship will help us in understanding the individuality of transnational entrepreneurs.

\section{TRANSNATIONAL ENTREPRENEURS}

Recently the research has focused on entrepreneurs engaged in business at two different countries, and which are mainly related by international business (IB). It was argued that international business (IB) and entrepreneurs dealing in two different countries do vary in scope and nature of engagement (Dana et.al, 1999). International business (IB) is related to $\mathrm{MNC}$ dealing with production and marketing in different countries where as entrepreneurs dealing in two different countries are related to new venture creation(Adiguna et.al, 2012).Further they are termed as International Entrepreneurs, Ethnic entrepreneurs and Transnational Entrepreneurs by different researchers (Adiguna et.al, 2012). Authors from different disciplines have tried to distinguish these teams on the basis of scope of their operation. Accordingly International entrepreneurs are those who evolves in the process of transformation from domestic firm to international firm (McDougall \& Oviatt, 2000), it can also be referred as business expansion beyond the boundaries of home country. International entrepreneurs already have a set and well established venture in home country and wants to find new market and new manufacturing places outside the home country. Comparable example for international entrepreneurs originated from Indian are Kiran Mazumdar Shaw of Biocon, Bhavarlal Jain of Jain Irrigations. Ethnic entrepreneurs are those whose origin is linked to a common social system and cultural heritage, (Kloosterman et.al, 1998; Rath \& Kloosterman, 2000; Yinger, 1985) the ethnic originate is the center of their individuality, social relations, and economic transactions (Aldrich \& Waldinger, 1990). Ethnic entrepreneurs are generally immigrants from home country for different regions, they often have distinctive language and customs. The business activity they engage are tied with ethnic originate hence they manufacture unique set of goods and services. Comparable examples for ethnic entrepreneurs are immigrant Tibetans to India and immigrant Punjabi's at Canada. Transnational entrepreneurs are one who migrated from home country to other country in seeking to explore business opportunities and also maintain business relations with home country hence deal and adapt to two different conditions. The argument about the nature and scope of business of International Entrepreneurs, Ethnic entrepreneurs and Transnational Entrepreneurs are still contradictory. The common misunderstanding in describing entrepreneurs dealing in two different countries is explained by Drori, Honig, \& Wright, (2009). According to Drori et al, (2009) "entrepreneurs that migrate from one country to another, concurrently maintaining business-related linkages with their former country of origin and currently adopted countries and communities" This indicate that entrepreneurs in the process of new venture need to deal in two different environments.

Further it is argued that similar to the process of new venture creation, transnational entrepreneurs need to acquire economic resources referring to money and material possessions and along with economic resources it is equally important to have social, cultural and symbolic resources (Terjesen \& Elam, 2009). Social resources refers to social relationships (with family, friends etc) and network for operation of business activity (Terjesen \& Elam, 2009; Portes 1998), cultural resources give identity for transnational entrepreneurs and use as competitive advantage in developing new venture creation(Portes et al, 2002). Symbolic is about status and power which in turn reinforces cultural and business artifacts such as awards and recognition (Terjesen \& Elam, 2009).The literature mainly highlights about the nature and scope of the transnational entrepreneurs (Drori et al, 2009) and resources required for new venture creation under two different circumstances (Terjesen \& Elam, 2009). 
The limitations of existing literature on transnational entrepreneurs are:

a) It has not concentrated on individuality (personality traits and behavioral aspects) of transnational entrepreneurs.

b) It has not highlighted on the antecedent factors affecting the growth of transnational entrepreneurs (like transnational entrepreneurs entrepreneurial potential, motivation, leadership shills etc)

c) Limited to the scope, nature and resources required

It has been argued that trait approach has not been successful in explaining the entrepreneurship or new venture creation process (Gartner, 1988) and searching for entrepreneurial personality is compared to ghost hunting (Shaver, 1995). Despite the criticism and counter arguments, almost all authors in the entrepreneurship research assumed that entrepreneurs have distinct trait or behavior. The most mentioned trait or behavior are autonomy, high achievement motivation, assertiveness, self-confidence, need for control, internal locus of control independence, single mindedness, initiative, optimism, imagination, persistence, decisiveness, competitiveness and risk taking (Cromie, 2000; Deakins, 1999; Koh, 1996). Psychological based research has reinforced curiosity in entrepreneurs' personal characteristics as predictors of achievement by moving ahead of the past focus on traits to learn competencies, motivation, cognition and behavior. (Baum\&Locke, 2004). This evolution in the field of entrepreneurship research initiates further investigation of key personality and behavioral factors from different dimensions.

The individuality of the transnational entrepreneur, like personality, behavior and motivation are still untouched. Entrepreneurial research from the past has been developed with this big debate of personality, behavior and motivation factors (Hamilton and Harper, 1994). It would be a mistake to completely neglect the individuality of the entrepreneur's personality and motivations (Brandstatter, 1997) and since motivation plays valuable role in creation of new venture, any new venture creation theory without involving motivation will be incomplete (Herron et.al, 1992). It is also stated that motivation and individual interest are the major abilities of transnational entrepreneurs to gain competitive advantage against other players in multiple environment (Bourdieu \& Wacquant, 1992). Even from the dimension of identifying entrepreneurial opportunity, entrepreneurial researchers have concluded that individuals with high self-efficacy and more internal locus of control are more likely to identify and explore entrepreneurial opportunity (Chen et.al, 1998). Further (McClelland, 1961) individuals with high need for achievement motivation will succeed in exploring opportunities. Since transnational entrepreneurs deals in more complex business environment, high need for achievement and self-efficacy are critical in new venture creation and development. The existing literature on transnational entrepreneurs on the other side is limited to explain about the nature and scope of new venture and resources required to dealing with two different business environments. It is also unclear whether or not that individuality of conventional entrepreneurs will hold true for transnational entrepreneurs.
Further it is also unclear whether or not these relationships hold true in all cases, or whether they vary depending on regional context, gender, and national group. This research gap is used as the foundation for further analysis. This leads us to incomplete understanding about transnational entrepreneurs.

\section{ENTREPRENEURSHIP RESEARCH}

Entrepreneurship is the projected act of an individual or a team of individuals to start, maintain or enhance profit by production or distribution of economic goods and services. It is a process of new venture creation associated with characteristics of individual(s), the organization, the environment surrounding and the process of creation (Gartner, 1985). An entrepreneurship is mainly referred to the process of action on entrepreneur undertakes to establish his/her enterprise (Desai, 2001). Entrepreneur is an individual who possess and lead the activities of entrepreneurship, i.e. one who is self employed, who starts, organizes, manages and takes responsibility of business activity, and the intend to lead those who are willing to work under him (Segal et.al. 2005).

It was at the beginning of $18^{\text {th }}$ century, the idea of profit maximization leading to motivation of entrepreneurial activity (Long, 1982). The real push was at the middle of The Industrial revolution in Britain entrepreneurs evolved and began to adjust new demand of growing industrial development, "limited liability" enacted in UK's Companies Act 1856 has enhanced the growth of entrepreneurs (Hamilton \& Harper, 1994). At this stage entrepreneurial function was mainly associated and limited to firms operation, it didn't emphasize on new venture creation (Hamilton \& Harper, 1994). Even in later studies entrepreneurship need not be the creation of new organization but it can also be seen in the existing organization (Amit et.al, 1993). Industrial revolution is associated with rapid advancement in technology. Due to this dynamic in business a new paradigm have emerged like entrepreneurship, innovation, industrial dynamics and job creation (Acs, 1992). Simultaneously there is shift in focus from large companies to small firms, the evolution of small industry/small firm fueled by change in world economy, intense computation in global stage, uncertainty in business environment and fragmentation in market (Carlsson, 1992). Many researchers connected both technological advancement and evolution of small firms and took "Schumpeterian" view of innovation and creativity as a base for entrepreneurial study (Landstrom, 2008). "Schumpeterian model" emphasize on to bring new form of production by innovation or innovative technology for the production of new products or producing old products in new and much better way or new way of distribution and service of products (Schumpeter, 1976).

With this understanding about entrepreneurs the research in the area of entrepreneurship has emerged and evolved in different dimensions. The primary focus was on the supply of entrepreneurs and why do some people can and others can't become entrepreneurs? (Landstrom, 2008). The study was divided in three different dimensions, economic perspective, psychological and perspective of entrepreneurship (Hamilton $\&$ Harper, 1994). Economic perspective is rooted on the basis 
of equilibrium between benefit received as labor and selfemployment (Johnson \& Dernell, 1975). Psychological and social perspective in contradiction with economic perspective argues that supply/growth of entrepreneurs cannot be studied by one dimension hence entrepreneurial activity is associated with personality, social, environmental, and cultural variables so it be studied in all dimensions (Hamilton \& Harper, 1994).

Psychological based research has reinforced curiosity in entrepreneurs' personal characteristics as predictors of achievement by moving ahead of the past focus on traits to learn competencies, motivation, cognition and behavior. (Baum \& Locke, 2004). This evolution in the field of entrepreneurship research initiates further investigation of key personality and behavioral factors from different dimensions. Entrepreneurial potential is identified as a major precursor of entrepreneurial activity (Krueger and Brazeal, 1994) and achievement motivation is another such factor which has distinguished itself apart from other traits in being a variable predictor (Hansemark, 2003).Leadership skills are also related elements which act as binding agent of all major components of entrepreneurship (Prieto, 2010), and also act as a starting agent for entrepreneurial activity.

The role of individual factors, like need for achievement motivation, entrepreneurial potential and (Brindley, 2005; Guerrero et al., 2008; Krueger, 2009; Krueger and Brazeal, 1994) leadership skills (Swiercz \& Lydon, 2002; Vecchio, 2003) are the focus of research investigating entrepreneurial behavior (Chell, 1986; Chell et al., 1991; Ghulam et al., 2006; Harris and Gibson, 2008; Low and MacMillan, 1988; Moran, 1998).Entrepreneurial potential is the significant predecessor for entrepreneurship (Krueger and Brazeal, 1994), entrepreneurial potential will indicate the state of readiness towards entrepreneurial activity. Achievement motivation influences an individual to take up an entrepreneurial position in order to attain more achievement satisfaction than could be derived from other types of positions (Stewart et al., 2003). Leadership skill focuses on the cognitive and important processes through which entrepreneurial leaders bring together a group of people to achieve the entrepreneurial vision (Kempster\& Cope, 2010). Leadership skills are particularly vital for nascent entrepreneurs to step-into the process of entrepreneurship and at the beginning of a new business (Vecchio, 2003). Leadership skills of the individual entrepreneurs are another predecessor which empowers the nascent entrepreneurs towards success. The existing theory states that entrepreneurial potential is mainly affected by leadership skills and achievement motivation. The research studying relationship of leadership skills with entrepreneurial potential and achievement motivation are also limited.

\section{Entrepreneurial Potential}

Entrepreneurial potential is identified as major predecessor of entrepreneurial activity (Krueger \& Brazeal, 1994). The function of entrepreneurial potential is primarily focused on identifying the factors that may activate entrepreneurial behavior (Chell, 1986; Chell et al., 1991; Ghulam et al., 2006; Harris and Gibson, 2008; Low and MacMillan, 1988; Moran, 1998). Entrepreneurial potential in past research was referred in different contexts like purpose, preparedness or orientation captures the notion of pre vacant state of willingness within the individual to take up entrepreneurial opportunity (Ryan et.al. 2011). This prospective of entrepreneurial potential resting "within the individual" is important as it differentiate between the internal capability of individual and external instrumental resources that may be required to promote or pursue entrepreneurial activity (Ryan et.al. 2011).

Entrepreneurial potential helps in assessing the level of necessary pre-condition in existence that relate to success of future entrepreneurial action (Krueger, 2009). Different personality traits can be related to potential entrepreneurs like creativity, teamwork, sociability, temperament, flexibility, growth orientation (Macke and Markley, 2003; Thompson, 2004), desirability, intention (Guerrero et al. 2008), locus of control, and innovativeness (Mueller and Thomas, 2001).. Entrepreneurial potential is considered as an important factor which determines the intent to take up entrepreneurial activity and hence it is considered as the major variable for the study.

\section{Achievement Motivation}

McClelland (1961) has stated achievement motivation as the key psychological factor influencing the entrepreneurial activity, the conclusions were drawn on the basis of a strong empirical evidence tested under different conditions with high replicability. This laid a strong foundation for further entrepreneurial research. Achievement motivation theory emphasizes on both psychological and social drives which produce the entrepreneurial personality. Further (Herron et.al, 1992). States since motivation plays valuable role in creation of new venture, any new venture creation theory without involving motivation will be incomplete. It will lead to mistake if the individuality of the entrepreneur's personality and motivations are neglected (Brandstatter, 1997). (Naffziger et.al. 1994) describes motivation triggers the entrepreneurial behavior in individuals and motivation acts as the function of interaction between individual and the environment (Endler, 1983). So in the proposed research study need for achievement motivation (nAch) will be considered as one of the variables for the study. Achievement motivation (nAch) is a single such factor always found in an individual's for participating in entrepreneurial activity (Collins, et al, 2004). Achievement motivation (nAch) directly affects individual's willingness to develop their performance, consistently perform at greater level, strive for achievement and take greater liability (Loon \& Casimir, 2008; McClelland, 1985). Need for achievement motivation (nAch) will act as "predisposing" factor in directing career aspirations towards entrepreneurial activity (Scott \& Twomey, 1988). Recent research has also re-insisted the importance of individual traits and characteristics on entrepreneurial success (Baum \& Locke 2004; Trerelyon, 2008).

\section{Leadership Skills}

The major activity of entrepreneurs is to combine all factors of production together and to guide the firm activity. The individual characteristic of leadership is the center to entrepreneurial activity (Chen, 2007). Because entrepreneur's leadership skills are important in improving, individual, group and new business performance and success, it significantly influences entrepreneurial leadership potential in acting with 
highly volatile and competitive environment (Cogliser and Brigham 2004; D'Intino et al. 2007; Fernald et al. 2005; Frey, 2010; Gupta et al. 2004).Leadership is set a of developable skills (Katz, 1955). Leadership skills are defined as ability to use one's knowledge and competencies to accomplish a set of goals or objectives (Northouse, 2007). Fresh research have also showed both entrepreneurs and leaders are consciously emerging their personal and functional ability in order to face the new challenges of the present business world (Cope and Watts 2000; Cope 2005; Kempster, 2006; Young and Sexton, 2003). Leadership pushes the entrepreneurs to identify opportunity, step into a business design and cope with the challenges and problems related with entrepreneurship (Gupta et.al 2004; Swierez \& Lydon, 2002). To study the leadership in entrepreneur's transformational leadership and transactional leadership are considered. The term transformation leadership was first coined by Downton in 1973.Unlike other leadership approach transformational leadership and transactional leadership do not provide a clear set of assumptions about how leader should act in a particular situation to be successful, rather it is a general way of thinking about leadership that emphasizes ideas, inspiration, innovation, individual and rewards (Northouse, 2007). Hence it can be called as leadership skill instead of leadership style. Transformational leadership is the course of action in which a person (Entrepreneur) will be involve with others and develop link that rises the level of motivation and morality in both the leader and the followers (Northouse, 2007). Transformational leadership is more concerned with improving the performance of followers and developing followers to their full potential (Avolio, 1999; Bass \& Avolio, 1990) which closely connects entrepreneurs potential to motivation of his subordinates and succeed collectively. Transactional leadership on the other hand focuses on exchanging things of value with subordinates to advance their own and their subordinate's agendas (Kuhnert, 1994).

\section{PROPOSED CONCEPTUAL MODEL}

The insights from review of literature suggest entrepreneurship research towards analysis of transnational entrepreneurs lacks the individual aspects. It is also unclear whether or not that individuality of conventional entrepreneurs will hold true for transnational entrepreneurs. Further it is also unclear whether or not these relationships hold true in all cases, or whether they vary depending on regional context, gender, and national group. The conceptual framework is developed by analyzing the general individual aspect of the entrepreneur and comparing with transnational entrepreneurs. In spite transnational entrepreneurs new venture creation is different and complex in nature, the motivation and individual aspects of entrepreneurs will be common for all entrepreneurial activities (Herron et.al,1992).Immigrants have two choice in the host country, first one is to get wage employment and the second one is to start up business venture i.e. to be transnational entrepreneurs. In the recent research, it is found that transnational entrepreneurs are doing better than their co-immigrants who opted for wage employment (Logan et.al, 1994; Wilson and Martin, 1982).Transnational entrepreneurs will explore the opportunity that are existing in the host country and takes the help of home country in doing so(Dana et.al, 1999). This process need the economic and social judgment of two different environments, these judgments cannot be made by co-immigrants, who opt for wage employment. This leads us to the fundamental question of entrepreneurship why some individuals start new venture when others under similar condition don't? (Grantner, 1988). The question emphasizes on distinguishes between entrepreneurs and non entrepreneurs, successful entrepreneurs and unsuccessful entrepreneurs (Rayan et al, 2011).

H1: There is a significant difference in individuality (personality traits and behavior) between transnational entrepreneurs and other co-immigrants.

According to Schumpeter, in addition to surrounding environment the creation of new business and entrepreneurial momentum depend on the availability of prospective entrepreneurs (potential entrepreneurs) i.e. individuals possessing personality traits pooled with personal circumstances which are likely to use them in creating new business (Schumpeter, 1934). Further research also states that entrepreneurial potential is the by-product of entrepreneurial orientation and perception of opportunity (Mueller et.al, 2001). The entrepreneurial orientation is referred as psychological traits, attitudes, and values which are associated with motivation to engage in entrepreneurial activity (McClelland, 1961; Dunkelberg \& Cooper 1982; Hornaday \& Aboud, 1971; Timmons, 1978). The literature also shows that comparatively transnational entrepreneurs have high entrepreneurial potential than other co-immigrants. Entrepreneurial potential in the case of transnational entrepreneurs will distinguish entrepreneurs and nonentrepreneurs and act as major predecessor factor for initiating entrepreneurial activities.

\section{H2: Transnational entrepreneurs have significantly high entrepreneurial potential than other co-immigrants.}

The need for achievement seems to distinguish itself more than the others as a measure of a predictor of entrepreneurial activity by many studies (Hansemark, 2003). Achievement motivation alone is obviously not enough to completely explain why one would choose to undertake an entrepreneurial endeavor (Carraher et.al. 2010) but however, it does appear to be a key component (Cover and Johnson, 1976). The researchers have also identified entrepreneurial "orientation", as exhibited by factors such as a degree of "autonomy, innovativeness, and risk taking" and attitudes and behaviors as key resource requirements for the gestation of entrepreneurial economic activity (Ryan et.al. 2011). Thus along with need for achievement motivation, entrepreneurial potential will act as required ability to engage in entrepreneurial activity. For entrepreneurship to evolve there must be an entrepreneurial orientation and potential in place, and the need for achievement as conceptualized by McClelland may contribute significantly to this orientation/potential (Ryan et.al. 2011). Thus from the above literature there exist a relationship among entrepreneurial potential and transnational entrepreneurs. 


\section{H3: Transnational entrepreneurs have significantly high need for achievement than other co-immigrants.}

Entrepreneurs requires precise leadership skills to be successfully and to overcome hurdles, difficulties and to achieve the entrepreneurial goals (Anderson \& Jack, 2008; Gupta et.al. 2004; Swiercz \& Lydon, 2002) in these model transnational entrepreneurs faces numerous challenges. Recent research findings on new business development shows, actions result in the buildup of resources, the set up of organizational boundaries, and the starting of exchanges with other parties surrounding the business, thereby bringing forth the growth of a new organization (Brush et.al. 2008).Entrepreneurial leadership is not similar from other type of leadership skills, it uses to collect and channelize resources for innovation and exploitation of tactical value development (Gupta et.al. 2004). These leadership skills are mainly critical for emerging entrepreneurs to jump into the process of entrepreneurship and at the main stage of a new business creation (Vecchio, 2003). The early definitions of entrepreneurial leadership paying attention on personal attributes and characteristics of entrepreneurial leaders (Swiercz \& Lydon, 2002; Vecchio, 2003), more latest definitions focus on the interpersonal and influential skills through which entrepreneurial leaders channelizes a group of people to achieve the entrepreneurial ideas (Kempster \& Cope, 2010). In this context, an entrepreneurial leadership skill is the process of social influence, transformation, and empowering in rapidly changing and uncertain contexts (Kempster \& Cope, 2010; Gupta et.al.2004). (Yang, 2008) Study focuses that there are significantly strong relationships between entrepreneurial orientation, transformational leadership, and subsequently moderate relationship existing among transactional leadership.

H4: Transnational entrepreneurs have significantly high leadership skills than other co-immigrants.

Recent research on new business creation indicates, activities result in the gathering of resources, the founding of organizational boundaries, and the start of exchanges with other parties in the environment, thereby bringing forth the emergence of a new business (Brush et.al. 2008). Entrepreneurial potential is the state of readiness to engage in business or start up new venture creation (Krueger \& Brazeal, 1994). Earlier research has also indicated that entrepreneurial potential has positive relational with students (Ryan et.al. 2011). Entrepreneurial leadership is very different from other forms of leadership skill, it uses to collect and channelize resources for innovation and exploitation of strategic value creation (Gupta et.al. 2004). Achievement motivation acts as the initiation factor to start up entrepreneurial activity and leadership skills act as a lead initiator and helps in nascent stages of transnational entrepreneurial activity. The literature shows that entrepreneurial potential, leadership skills and achievement motivation will significantly affect success of transnational entrepreneurs
H5: Entrepreneurial potential, need for achievement motivation and leadership skills will positively affect the success of transnational entrepreneurs.

This is a framework for exploring the individual qualities of transnational entrepreneurs. These are the hypotheses developed on the basis of strong literature background and gaps from the past research on transnational entrepreneurs. The frame work provides the road map for further exploration about the individuality of transnational entrepreneurs. The testing of the hypothesis need to be conducted in suitable environment for further clarity on transnational entrepreneurs.

\section{CONCLUSION}

Entrepreneurship research has come a long way towards the era of globalization. The significant growth of entrepreneurial activities in different dimensions asks complex questions. Transnational entrepreneurship is a new paradigm of entrepreneurial studies, with new challenges for the researchers and policy makers. Transnational entrepreneurial researches have mainly concentrated on sociological aspects and clearly lack the individual aspects. Individual approach is the key for thoughtful understanding of new business creation and explains what are the factor that triggers the transnational entrepreneurial activities. The key individual factors like entrepreneurial potential, leadership skills and need for achievement motivation will play critical role in new venture creation. This also holds well in the case of transnational entrepreneurs, even if the circumstance in which transnational entrepreneur's deals is different.

The current study contribute to the emerging literature on transnational entrepreneurship by taking a step towards examining the transnational entrepreneurs individuality factors like entrepreneurial potential, achievement motivation and leadership skills responsible for new venture creation and success. The current study was conducted in a unique context, which bears limitations as well as merits. The limitations may be, the individuality is limited only to three contexts of entrepreneurial potential, achievement motivation and leadership skills, there may be other individuality aspects which trigger transnational entrepreneurial activity and affect the success of transnational entrepreneurs. But this study provides the road map for such explorations. The merit of the study is the approach towards individuality of transnational entrepreneurs, which need to be explored for better understanding of transnational entrepreneurs. We are fascinated to explore the gap in the literature and develop the relevant hypothesis, further the hypothesis need to be tested to understand the phenomenon of transnational entrepreneurship. This is a small effort in our learning process of entrepreneurship research and hope our contribution will add value to entrepreneurship research. 


\section{REFERENCES}

[1] Z.J. Acs, "Small business economics: a global perspective," Challenge, Vol. 35, Pp.38-44, 1992.

[2] R. Adiguna, S. Shah, and F. Habib, "Exploring Transnational Entrepreneurship: On the Interface between International Entrepreneurship and Ethnic Entrepreneurship," Unpublished thesisJonkoping University, Sweden, 2012.

[3] H. Aldrich, and R. Waldinger, "Ethnicity and entrepreneurship," Annual Review of Sociology, Vol.16, Pp.111-135, 1990.

[4] R. Amit, L. Glosten, and E. Muller, "Challenges to theory development in entrepreneurship research," Journal of Management Studies, Vol. 30, No. 5, Pp.815-34, 1993.

[5] A.R. Anderson, and S.L. Jack, "Role typology for enterprising education: The professional artisan," Journal of Small Business and Enterprise Development, Vol. 15, No. 2, Pp.256-273, 2008.

[6] B.J. Avolio, "Full Leadership Development: Building the vital forces in organizations," Thousand Oaks, CA: SAGE, 1999.

[7] S. Bagwell, "Transnational family networks and ethnic minority business development The case of Vietnamese nail-shops in the UK," International Journal of Entrepreneurial Behavior \& Research, Vol. 14, No. 6, Pp.377-394, 2007.

[8] B.M. Bass, and B.J. Avolio, "The Implications of Transactional and Transformational Leadership For Individual, Team, and Organizational Development," Research in Organizational Change and Development, Vol.4, Pp.231-272, 1990.

[9] J.R. Baum, and E.A. Locke, "The relationship of entrepreneurial traits, skills, and motivation to subsequent venture growth", Journal of Applied Psychology, Vol.89, No.4, Pp.587-598, 2004.

[10] W.J. Baumol, "Entrepreneurship in economic theory," American Economic Review, Vol. 58, No. 2, Pp.64-71, 1968.

[11] P. Bourdieu, and L. Wacquant, "Introduction to Reflexive Sociology," University of Chicago Press: Chicago, 1992.

[12] C.G. Brush, T.S. Manolova, and L.F. Edelman, "Properties of emerging organizations: An empirical test," Journal of Business Venturing, Vol.23, No.5, Pp.547-566, 2008.

[13] H.Brandstatter, "Becoming an entrepreneur: A question of personality structure," Journal of Economic-Psychology, Vol.18, Pp.157-177, 1997.

[14] C.Brindley, "Barriers to women achieving their entrepreneurial potential," International Journal of Entrepreneurial Behaviour\&Research, Vol.11, No.2, Pp.144-161, 2005.

[15] B. Carlsson, "The rise of small business: causes and consequences," Adams, W.J. (Ed.), Singular Europe, Economy and Policy of the European Community after 1992, University of Michigan Press, Ann Arbor, MI.

[16] S.M. Carraher, J.K. Buchanan, and G. Puia, "Entrepreneurial Need for Achievement in China, Latvia, and the USA," Baltic Journal of Management, Vol. 5, No.3, Pp.378-396, 2010.

[17] E. Chell, "The entrepreneurial personality: a review and some theoretical developments", Curran, J., Stanworth, J. and Watkins, D. (Eds), The Survival of the Small Firms, Gower, Aldershot, Pp.102-19, 1986.

[18] E. Chell, J. Haworth, and S. Brearley, The Entrepreneurial Personality, Routledge, London, 1991.

[19] C. Chen, P. Greene, and A. Crick, "Does entrepreneurial self-efficacy distinguish entrepreneurs from managers," Journal of Business Venturing, Vol.13, Pp.295-318, 1998.

[20] M.H. Chen, "Entrepreneurial leadership and new ventures: Creativity in entrepreneurial teams," Creativity and Innovation Management, Vol. 16, No. 3, Pp.239-249, 2007.

[21] C.C. Cogliser, and K.H.Brigham, "The intersection of leadership and entrepreneurship: Mutual lessons to be learned," The Leadership Quarterly, Vol.15, Pp.771-799, 2004.

[22] C.J. Collins, P.J. Hanges, and E.A. Locke, "The relationship of achievement motivation to entrepreneurial behavior: A meta-analysis," Human Performance, Vol. 17, No. 1, Pp.95-117, 2004.

[23] J. Cope, "Toward a dynamic learning perspective of entrepreneurship," Entrepreneurship Theory and Practice Vol. 29, No. 4, Pp.373-397, 2005.

[24] J. Cope, and G. Watts, "Learning by doing: An exploration of experience, critical incidents and reflection in entrepreneurial learning," International Journal of Entrepreneur-ship Behaviour and Research, Vol. 6, No. 3, Pp.104-124, 2000.

[25] J.D. Cover, and N.R. Johnson, "Need achievement, phase movement and the business cycle," Social Forces, Vol. 54, No. 4, Pp.760-774, 1976.
[26] S.Cromie, "Assessing entrepreneurial inclination. Some approaches and empirical evidence," European Journal of Organizational Psychology, Vol. 9, Pp.7-30, 2000.

[27] R.S. D’Intino, M.G. Goldsby, J.D. Houghton, and C.P. Neck, "Selfleadership: A process for entrepreneurial success," Journal of Leadership and Organizational Studies, Vol. 13, No.4, Pp.105-120, 2007.

[28] L.P. Dana, H. Etemad, and R.W. Wright, "Theoretical Foundations of International Entrepreneurship," Global Strategic Management, Vol. 7, Pp.3-22, 1999.

[29] D. Deakins, Entrepreneurship and Small Firms, McGraw-Hill, London, 1999.

[30] Desai, Vasant, Small-Scale Industries and Entrepreneurship, Himalaya Publishing House, Mumbai, 2001.

[31] I. Drori, B. Honig, and M. Wright, "Transnational Entrepreneurship: An Emergent Field of Study," Entrepreneurship Theory and Practice, Vol.33, No.5, Pp.1001-1022, 2009.

[32] W.C. Dunkelberg, and A.C. Cooper, Entrepreneurial typologies, K.H. Vesper (Ed.). Frontiers of entrepreneurship research. MA: Babson college, 1982.

[33] N.S. Endler, Interactionism: A personality modelbut not yet a theory, In M.M. page \& R Dienstbier (Eds), Symposium on motivation,. Lincoln. University of Nebraska Press pp155-200, 1983

[34] L.W. Fernald, G.T. Solomon, and A. Tarabishy, "A new paradigm: Entrepreneurial leadership," Southern Business Review, Vol. 30, No. 2, Pp.1-10, 2005.

[35] R.S.Frey, "Leader self-efficacy and resource allocation decisions: A study of small business contractors in the federal market space," USASBE Proceedings, Pp.781-810, 2010.

[36] W.B. Gartner, "Who is an entrepreneur? Is the wrong question," American Journal of Small Business, Spring, Pp.11-32, 1988.

[37] W.B. Gartner, "A framework for describing the phenomenon of new venture creation," Academy of Management Review, 10, 696-706, 1985.

[38] N. Ghulam, R. Holden, and A. Walmsley, "Graduate career-making and business start-up: a literature review," Education + Training, Vol. 48, No. 5, Pp.373-385, 2006.

[39] M. Guerrero, J. Rialp, and D. Urbano, "The impact of desirability and feasibility on entrepreneurial intentions: a structural equation model," International Entrepreneurship and Management Journal, Vol.4, No.1, Pp.35-50, 2008.

[40] V. Gupta, I.C. MacMillan, and G. Surie, "Entrepreneurial leadership: Developing and measuring a cross-cultural construct," Journal of Business Venturing, Vol.19, Pp.241-260, 2004.

[41] R.T. Hamilton, and D.A. Harper, "The entrepreneur in theory and practice," Journal of economic studies, Vol. 20, No.06, Pp.3-18, 1994

[42] O.C. Hansemark, "Need for achievement, locus of control and the prediction of business start-ups: A longi-tudinal study," Journal of Economic Psychology, Vol.24, No.3, Pp.301-319, 2003.

[43] M.L. Harris, and S.G. Gibson, "Examining the entrepreneurial attitudes of US business students," Education + Training, Vol.50, No.7, Pp.568$581,2008$.

[44] Herron, Lanny., Sapienza, and J.Harry, "The entrepreneur and the initiation of new venture launch activities," Entrepreneurship: Theory and Practice, Vol. 17, No.1, Pp.49-55, 1992.

[45] J.A. Hornaday, and J. Aboud, "Characteristics of successful entrepreneurs, "Personnel Psychology, Vol. 24, Pp. 141-153, 1971.

[46] P.S. Johnson, and A. Darnell, "New Firm Formation in Great Britain", Working Paper No. 5, Dept of Economics, University of Durham, 1976.

[47] R.L.Katz, "Skill of an effective administrator," Harvard Business Review, Vol.33, No.1, Pp.33-42, 1955.

[48] S.J. Kempster, and J.Cope, "Learning to lead in the entrepreneurial context," Journal of Entrepreneurial Behavior and Research, Vol.16, No.6, Pp.5-34, 2010.

[49] S.J. Kempster, "Leadership learning through lived experience: A process of apprenticeship," Journal of Management and Organization, Vol.129, No.1, Pp.4-22, 2006.

[50] R. Kloosterman, J. Van der Leun, and J. Rath, "Across the border: Immigrants' economic opportunities, social capital, and informal business activities," Journal of Ethnic and Migration Studies, Vol.24, No.2, Pp.249-268, 1998

[51] H.C. Koh, "Testing hypotheses of entrepreneurial characteristics," Journal of Managerial Psychology, Vol.11, Pp.12-25, 1996.

[52] N. Krueger, and D. Brazeal, "Entrepreneurial Potential and Potential Entrepreneurs," Entrepreneurship: Theory and Practice, Vol.18, No.3, Pp.91-104, 1994. 
[53] N.F. Krueger, "Entrepreneurial intentions are dead: long live entrepreneurial intentions", Carsrud, A.L. and Brannback, M. (Eds), Understanding the Entrepreneurial Mind, Vol. 24, Pp. 51-72, 2009,

[54] K.W. Kuhnert, "Transforming leadership: Developing people through delereguation," B.M. Bass \& B.J. Avolio (Eds.), Improving organizational effectiveness through transformational leadership. Thousand Oaks, CA: Sage, Pp.10-25, 1994.

[55] D.F. Kuratko, "Entrepreneurial leadership in the 21st century," Journal of Leadership and Organizational Studies, Vol.13, No.4, Pp.1-11, 2007.

[56] D.F. Kuratko, "Entrepreneurship," International Encyclopedia of Business and Management, $2^{\text {nd }}$ ed. (London: Routledge Publishers, Pp.168-176, 2002.

[57] H.Landstrom, "Entrepreneurship research: A missing link in our understanding of the knowledge economy," Journal of Intellectual Capital, Vol.9, No.2, Pp.301-322, 2008

[58] I. Light, "Global Entrepreneurship and Transnationalism," Dana, L.P. (ed). Handbook of Research on Ethnic Minority Entrepreneurship, Edward Elger, Pp.3-15, 2007.

[59] I. Light, and S.J. Gold, Ethnic Economies, Academic Press, San Diego, CA, 2000.

[60] Logan, R. John, Richard D. Alba., and Thomas L. McNulty, "Ethnic Economies in Metropolitan Regions: Miami and Beyond," Social Forces, Vol. 72, Pp.691-724, 1994.

[61] W.Long, "The meaning of entrepreneurship," American Journal of Small Business, Vol.8, No.2, Pp.47-49, 1982

[62] M. Loon, and G. Casimir, "Job-demand for learning and job-related learning: the moderating effect of need for achievement," Journal of Managerial Psychology, Vol.23, No.1, Pp.89-102, 2008.

[63] M.B. Low, and I.C. MacMillan, "Entrepreneurship: past research and future challenges," Journal of Management, Vol. 14, No.2, Pp.139-61, 1988.

[64] D. Macke, and D. Markley, "Entrepreneur Self-test," The Center for Rural Entrepreneurship, 2003,

[65] D.C. McClelland, The Achieving Society, D. Van Nostrand Co., Princeton, NJ, 1961.

[66] D.C. McClelland, Human Motivation, Cambridge University Press, New York, NY, 1985.

[67] P. McDougall, and B. Oviatt, "International entrepreneurship: The intersection of two research paths," Academy of Management Journal, Vol.43, No.5, Pp.902-908, 2000.

[68] P. Moran, "Personality characteristics and growth-orientation of the small business owner-manager," International Small Business Journal, Vol.16, No.3, Pp.17-38, 1998.

[69] S.L. Mueller, and S. Goic, "Entrepreneurial potential in transition economies:A view from tomorrows leaders," Journal of Developmental Entrepreneurship, Vol.7, No.4. Pp.399-414, 2002.

[70] S.L. Muller, A.S. Thomas, and A.M. Jaeger, "National entrepreneurial potential: The role of culture, economic development, and political history," Advance in comparative management, 2001.

[71] Naffziger, W.Douglas, Hornsby, S.Jeffrey, Kuratko, and F. Donald, "A Proposed Research Model of Entrepreneurial Motivation," Entrepreneurship: Theory and Practice, Vol.18, No.3, Pp.29-42, 1994.

[72] P.G. Northouse, Leadership Theory And Practice (Fourth ed.). SAGE Publications, Inc, 2007.

[73] A. Portes, "The social origins of the Cuban enclave economy of Miami," Sociological Perspectives, Vol.30, Pp.340-372, 1987.

[74] A. Portes, "Social Capital: Its Origin and Applications in Modern Sociology," Annual Review of Sociology, Vol.24, No.1, Pp.1-24, 1998.

[75] A. Portes, L.E. Guarnizo, and W.J. Haller, "Transnational Entrepreneurs: An Alternative Form of Immigrant Economic Adaptation," American Sociological Review, Vol.67, No.2, Pp.278-298, 2002.

[76] L.C.Prieto, "Proactive personality and entrepreneurial leadership: exploring the moderating role of organizational identification and political skill," Academy of Entrepreneurship Journal, Vol.16, No.2, Pp.107-122, 2010.

[77] J., Rath, and R. Kloosterman, "A critical review of research on immigrant entrepreneurship," International Migration Review, Vol.34, No.3, Pp.657-681, 2000.

[78] L.Riddle, "Diasporas: Exploring their development potential," ESR Review, Vol.10, No.2, Pp.28-36, 2008.

[79] J.C. Ryan, S.A.Tipu, and R.M. Zeffane, "Need for achievement and entrepreneurial potential: a study of young adults in the UAE," Education, Business and Society: Contemporary Middle Eastern Issues, Vol.4, No.3, Pp.153-166, 2011.
[80] A. Saxenian, The New Argonauts: Regional Advantage in a Global Economy. Boston: Harvard University Press, 2006.

[81] J.A .Schumpeter, The Theory of Economic Development: An Inquiry into Profits, Capital, Credit, Interest and the Business Cycle, Harvard University Press, Cambridge, MA, 1934.

[82] J.A. Schumpeter, Capitalism, Socialism and Democracy, 5th ed., George Allen and Unwin, London, 1976.

[83] M.G. Scott, and D.F. Twomey, "Long-term supply of entrepreneurs: student career aspirations in relation to entrepreneurship," Journal of Small Business Management, Vol.26, No.4, Pp.5-13, 1988.

[84] G. Segal, D. Borgia, and J. Schoenfeld, "The motivation to become an entrepreneur," International Journal of Entrepreneurial Behavior \& Research, Vol.11, No.1, Pp.42-57, 2005.

[85] K. Shaver, "The entrepreneurial personality myth", Business and Economic Review, Vol.41, Pp.20-3, 1995

[86] W.H. Stewart, J.C. Jr Carland, J.W. Carland, W.E Watson, and R. Sweo, "Entrepreneurial dispositions and goal orientations: a comparative exploration of United States and Russian entrepreneurs," Journal of Small Business Management, Vol.41, No.1, Pp.27-46, 2003.

[87] P.M. Swiercz, and S.R.Lydon, "Entrepreneurial leadership in high-tech firms: a field study," Leadership and Organization Development Journal, Vol.23, No.7, Pp.380-386, 2002.

[88] S. Terjesen, and A. Elam, "Transnational Entrepreneurs' Venture Internationalization Strategies: A Practice Theory Approach," Entrepreneurship Theory and Practice, Vol.33, No.5, Pp.1093-1120, 2009.

[89] J.L. Thompson, "The facets of the entrepreneur: identifying entrepreneurial potential," Management Decision, Vol.42, No.2, Pp.243258, 2004.

[90] J.A. Timmons, "Characteristic and role demands of entrepreneurship," American Journal of Small Business, Vol. 3, 1978.

[91] R.Trevelyan, "Optimism, overconfidence and entrepreneurial activity," Management Decision, Vol.46, No.7, Pp.986-1001, 2008.

[92] R.P. Vecchio, "Entrepreneurship and leadership: common trends and common threads,"Human Resource Management Review, Vol.13, No.2, Pp.303-327, 2003.

[93] Wilson, Kenneth, Martin, and Allen, "Ethnic enclaves: a comparison of the Cuban and Black economies in Miami," American Journal of Sociology, Vol. 88, Pp.135-60, 1982.

[94] J.M. Yinger, "Ethnicity," Annual Review of Sociology, Vol. 11, Pp.151-180, 1985.

[95] J.E. Young, and D.L. Sexton, "What makes entrepreneurs learn and how do they do it?," Journal of Entrepreneurship, Vol. 12, Pp.155-182, 2003. 